\title{
STRUCTURE AND ABSOLUTE CONFIGURATIONS OF DICTYOTA SP. DITERPENES
}

\author{
A. G. GonZÁlez, * J. D. Martín M. NoRTE and P. Rivera \\ Instituto Universitario de Química Orgánica, La Laguna and Instituto de Productos Naturales Orgánicos, \\ CSIC, La Laguna, Teneriffe, Canary Islands, Spain \\ and \\ A. PERAles and J. Fayos \\ Departamento de Rayos-X, Instituto Rocasolano, Serrano 119, Madrid 6, Spain
}

(Received in UK 13 December 1982)

\begin{abstract}
Eight diterpenes belonging to the dolostane carbon skeleton have been isolated from the Canary Island brown alga Dictyota sp. The structures including absolute configuration of these diterpenes were secured by X-ray analysis of the triol derivative 7 followed by chemical interconversions.
\end{abstract}

The genus Dictyota, brown seaweeds of the Dictyotaceae family, is yielding an expanding variety of interesting diterpenoids. ${ }^{1}$ We wish to describe here the structures including absolute configuration of seven diterpenoids (2-3 and 5-9) isolated from the Dictyota sp. collected near La Graciosa, Canary Islands, during the Bentos I Expedition. ${ }^{2}$ Air-dried alga was extracted with acetone and the condensed extract chromatographed over silica gel (open column), using solvents of increasing polarity from $n$-hexane to ethyl acetate. ${ }^{3}$

Concentration of the extract yielded the triol 7 $\left(\mathrm{C}_{20} \mathrm{H}_{32} \mathrm{O}_{3}\right)$ as a pure crystalline substance (long needles, m.p. $220^{\circ},\{\alpha\}_{\mathrm{D}}=-189(c, 0.1 \mathrm{MeOH})$. The detailed ${ }^{1} \mathrm{H}$ NMR and ${ }^{13} \mathrm{C}$-NMR analyses (Experimental) were consistent with the structure 7 , which was confirmed by $\mathrm{X}$-ray studies of the single crystal. Compound 7 crystallizes in orthorhombic system with four molecules in the cell $a=22.6211(4), b=11.4528(2)$ and $c=7.4452(2) \AA$; $\rho_{x}=1.104 \mathrm{~g} \mathrm{~cm}^{-3}$. A crystal of $0.32 \times 0.30 \times 0.18 \mathrm{~mm}$ was used to measure the intensities of the 1899 independent Friedel pairs up to $\theta=65^{\circ}$. Data were collected on a computer-controlled four-circle diffractometer, using graphite-monochromated $\mathrm{CuK} \alpha$ radiation $(\lambda=1.5418 \AA)$ and $\omega / 2 \theta$ scan at $\sim 2 \% \mathrm{~min}$. No crystal decomposition was observed during the experiment. No absorption correction $\left(\mu=5.36 \mathrm{~cm}^{-1}\right)$ was done. The structure was solved by Multan ${ }^{4}$ and refined using the 1796 observed reflections with $1>2 \sigma(1)$. The $\mathrm{H}$ atoms were located on a difference map. After the molecular model was completed, a weighting scheme for the refinement was applied to prevent bias in $\left\langle w \Delta^{2} F\right\rangle$ vs $\left\langle F_{0}\right\rangle$ and vs $\langle\sin \theta \mid \lambda\rangle$. A last weighted anisotropic refinement (fixed isotropic contribution for $\mathrm{H}$ atoms), using both $h \mathrm{kl}$ and $\bar{h} \overrightarrow{k l}$, reflections converged to $R_{\mathrm{obs}}=0.042$ and $R w_{\mathrm{obs}}=0.054$.

Figure 1 shows the X-ray molecular model with the right absolute configuration, which was determined using those Bijvoet pairs (BP) with $F_{0}>10 \sigma\left(F_{0}\right)$ and greater $\Delta F_{c}{ }^{6}$ The averaged Bijvoet difference, $\langle\mathrm{BD}\rangle$, between

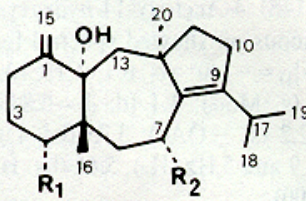

$\stackrel{1}{\sim} \mathrm{R}_{1}=\mathrm{OH} ; \quad \mathrm{R}_{2}=\mathrm{H}$

$2 \mathrm{R}_{1}=\mathrm{OH} ; \quad \mathrm{R}_{2}=\mathrm{OH}$

$3 R_{1}=O A C ; R_{2}=O H$

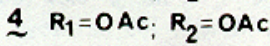<smiles>[R]C1CCC(=O)[C@@]2(O)C[C@]3(CC)CC[C@@](O)(C(C)C)[C@@]3(C)CC=C12</smiles>

$7 \mathrm{R}=\mathrm{OH}$

$8 R=O A C$

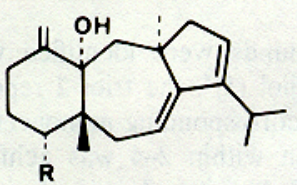

$5 \mathrm{R}=\mathrm{OH}$

6 $R=O A C$

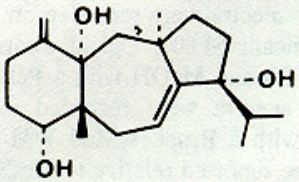

9 


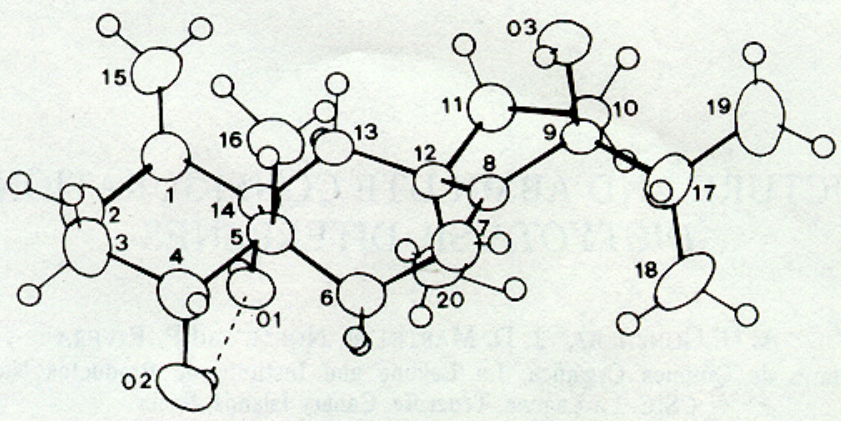

Fig. 1.

the $46 \mathrm{BP}$ with $\Delta F_{c}>0.15$ is 0.19 for the right enantiomer vs 0.33 for the wrong one. Using the $80 \mathrm{BP}$ with $\Delta F_{c}>$ $0.13,\langle\mathrm{BD}\rangle$ is 0.20 vs 0.29 .

The 6-membered ring is a chair with the best plane through the atoms $1-2-4-5$. The 7 -membered ring is also a chair with its best plane through atoms 5-6-12-13. The 5 -membered ring is a distorted envelope with the flap at $\mathrm{C}-10$. The length of the two double bonds $\mathrm{C}-1-\mathrm{C}-15$ and $\mathrm{C} 7-\mathrm{C} 8$ is $1.321(3) \AA$. The three $\mathrm{OH}$ groups are linked through $\mathrm{H}$-bonds, two intermolecular: $01 \mathrm{H} . \ldots 03$ of $2.75 \AA$ and $03 \mathrm{H} . .02$ of $2.77 \AA$; and one intermolecular $02 \mathrm{H}$. . 01 of $2.64 \AA$.

Treatment of 7 with $\mathrm{Ac}_{2} \mathrm{O} / \mathrm{Py}$ gave the also isolated monoacetate 8 which was dehydrated to the previously known compound 6 . $^{7}$ The absolute configuration of 6 is then determined as: $4(R), 14(S)$-dihydroxy-dolast-1 (15), 7, 9-triene.

The isolation of 7 , was recently reported from a mixture of the seaweeds $D$. linearis and $D$. divaricata collected in the Honduras Bay Islands. ${ }^{8}$ The structure was given on chemical and spectroscopic basis and the absolute configuration was undetermined.

The triol isomer $9\left(\mathrm{C}_{20} \mathrm{H}_{32} \mathrm{O}_{3}\right)$, m.p. $160-161^{\circ},\{\alpha\}_{\mathrm{D}}-59$ (c, $0.1 \mathrm{CHCl}_{3}$ ) gave on acetylation with $\mathrm{Ac}_{2} \mathrm{O} / \mathrm{Py}$ the monoacetate 6 as a result of concomitant dehydration at C-9. The $\mathrm{C}_{9}(\mathrm{OH})$ substituent and stereochemistry were confirmed by comparison of the ${ }^{1} \mathrm{H}-\mathrm{NMR}$ and ${ }^{13} \mathrm{C}-\mathrm{NMR}$ spectra with those of the related triol 7 (Experimental). The absolute configuration of 9 was established by the chemical correlation with 7 through the common dehydration derivative 6 .

The remaining compounds were identified with the previously reported amijiol $(\mathbf{1})^{9}$, the triol 2 reported by Crews et al., ${ }^{8}$ and their corresponding monoacetate (3). ${ }^{7}$ The chemical correlation within 2-4 was achieved by acetylation of $\mathbf{2}$ and $\mathbf{3}$ to give $\mathbf{4}$ and the absolute configuration determined by transformation of 4 into 6 by heating with DMSO.

\section{EXPERIMENTAL}

M.ps were determined on a Kofler block and are uncorr. IR spectra were recorded on a Perkin-Elmer Model 237 and Model 681 spectrophotometer. UV spectra were recorded on a PerkinElmer Model 137 or a Unicam SP800. Opical rotations were determined for solns in $\mathrm{CHCl}_{3}$ and $\mathrm{MeOH}$ with a Perkin-Elmer 141 polarimeter. ${ }^{1} \mathrm{H}-\mathrm{NMR}$ spectra were recorded on PerkinElmer R-32 $(90 \mathrm{MHz})$ and with a Brucker Mod WM 360 spectrometers, chemical shifts are reported relative to $\mathrm{Me}_{4} \mathrm{Si}(\delta 0)$ and coupling constants are given in hertz. ${ }^{13} \mathrm{C}$-NMR spectra were obtained on a Brucker Mod WM 360 and the chemical shifts are reported relative to $\mathrm{Me}_{4} \mathrm{Si}(\delta 0)$. Low and high resolution mass spectra were obtained from a VG Micromass ZAB-2F. Column and dry column chromatography were performed in silica gel $0.2-0.5$ and $0.005-0.20 \mathrm{~mm}$ respectively, and tlc and plc on silica gel G, all Merck products. Tlc plates were developed by spraying with $6 \mathrm{~N}-\mathrm{HSO}_{4}$ and heating. All solvents were purified by standard techniques. Anhyd $\mathrm{Na}_{2} \mathrm{SO}_{4}$ and $\mathrm{MgSO}_{4}$ were used for drying solns.

Collection and extraction. Collections were from a depth of -5 to $-10 \mathrm{~m}$, and location was near LaGraciosa Island (Canary Islands), October 1981, during the Bentos I expedition. The collection was immediately frozen and stored until extracted with acetone in a Soxhlet apparatus. Removal of solvent in vacuo yielded $48 \mathrm{~g}$ of dark green extract, which was subsequently chromatographed over silica gel (open column), using solvents of increaing polarity from $n$-hexane to EtOAc.

Amijol or (4S*, 14S*)-4, 14-Dihydroxydolast-1(15), 9 diene (1). Crystalline compound, m.p. $180^{\circ},\{\alpha\}_{\mathrm{D}}=-163\left(c, 0.3, \mathrm{CHCl}_{3}\right)$. This compound showed spectral features similar to those reported, ${ }^{9}$ and was identified by direct comparison with the natural product.

(4R, 14S)-Dihydroxydolast-1 (15), 7, 9-triene (5). This crystalline compound showed spectral features similar to those reported, ${ }^{7}$ m.p. $145^{\circ},\{\alpha\}_{\mathrm{D}}=-220^{\circ}\left(c, 0.15, \mathrm{CHCl}_{3}\right)$. MS: $m / z: 302$ $\left(\mathrm{M}^{+}-\mathrm{H}_{2} \mathrm{O}\right), 284,266,241$ and 223 . 'H-NMR $\left(360 \mathrm{MHz}, \mathrm{CDCl}_{3}\right)$ $\delta: 0.80\left(\mathrm{~s}, \mathrm{Me}_{16}\right) 1.07\left(\mathrm{~d}, \mathrm{~J}=6.8 \mathrm{~Hz}, \mathrm{Me}_{18}\right) ; 1.09(\mathrm{~d}, \mathrm{~J}=6.8 \mathrm{~Hz}$, $\mathrm{Me}_{19}$ ); 1.40 (s, Me 20 ); 2.40 (qq, J =6.8 Hz, H $\left.{ }_{17}\right) ; 2.90$ (ddd, J = 5.3 and $\left.13.7 \mathrm{~Hz}, \mathrm{H}_{2 \alpha}\right) ; 3.48\left(d d, J=4\right.$ and $\left.14 \mathrm{~Hz}, \mathrm{H}_{6 \alpha}\right) ; 3.87\left(\mathrm{bs}, \mathrm{H}_{4}\right)$ $4.77\left(\mathrm{~s}, \mathrm{H}_{15}\right) ; 4.91\left(\mathrm{~s}, \mathrm{H}_{15}\right) ; 5.45\left(\mathrm{dd}, \mathrm{J}=4.5\right.$ and $\left.9.5 \mathrm{~Hz}, \mathrm{H}_{7}\right) ; 5.57$ (s, $\left.\mathrm{H}_{10}\right)$. CMR (CDCl $\left.; 360 \mathrm{MHz}\right): 153.8$ (C-1); 31.67 (C-2); 31.35 (C-3); 80.31 (C-4); 44.03 (C-5); 27.23 (C-6); 114.17 (C-7); 149.8 (C-8); 152.4 (C-9); 109.5 (C-10); 50.95 (C-11); 45.5 (C-12); 43.5 (C-13); 82.05 (C-14); 109.6 (C-15); 19.9 (C-16); 26.74 (C-17); 22.13 (C-18); 22.3 (C-19); 25.7 (C-20). UV (EtOH) $\lambda_{\max }: 243 \mathrm{~nm}$ $(\epsilon 8.000)$.

(4R, 14S) 4-Acetoxy-14-hydroxydolast-1 (15), 7, 9-triene (6). This viscous oil showed spectral features similar to those reported. ${ }^{7}\{\alpha\}_{\mathrm{D}}=-140^{\circ}\left(c, 0.1, \mathrm{CHCl}_{3}\right)$. ${ }^{1} \mathrm{H}-\mathrm{NMR}\left(90 \mathrm{MHz}, \mathrm{CDCl}_{3}\right)$ $\delta: 1.00\left(\mathrm{~s}, \mathrm{Me}_{16}\right) ; 1.1\left(\mathrm{~d}, J=6.8 \mathrm{~Hz} ; \mathrm{Me}_{18}\right) ; 1.4(\mathrm{~d}, \mathrm{~J}=6.8 \mathrm{~Hz}$; $\mathrm{Me}_{19}$ ); 2.2 (s, - OAc); 3.75 (bs, $\mathrm{D}_{2} \mathrm{O}$ exch.); 4.90 (m, 3H); 5.39 (dd, $\mathrm{J}=9$ and $\left.5 \mathrm{~Hz}, \mathrm{H}_{7}\right) ; 5.65\left(\mathrm{bs}, \mathrm{H}_{10}\right)$; UV (EtOH) $\lambda_{\max }: 243 \mathrm{~nm}$ $(\epsilon: 10.000)$.

(4R, 7R, 14S)-4-Acetoxy-7, 14-dihydroxydolast-1 (15), 8-diene (3). A crystalline compound, m.p. $150^{\circ},\{\alpha\}_{\mathrm{D}}=-122^{\circ}(c, 0.1$, $\mathrm{CHCl}_{3}$ ). MS: $m / z: 362\left(\mathrm{M}^{+}\right), 344,320,319,302,301,259,241,223$. IR $\left(\mathrm{CHCl}_{3}\right): 3550,2940,1730,1640,1410,960$ and $910 \mathrm{~cm}^{-1}$. 'H-NMR: $0.78\left(\mathrm{~s}, \mathrm{Me}_{16}\right): 0.89$ (dd, J $\left.=6.8 \mathrm{~Hz}, \mathrm{Me}_{18}\right)^{*} ; 1.01$ (d, $\left.\mathrm{J}=6.8 \mathrm{~Hz}, \mathrm{Me}_{19}\right)^{*} ; 145$ (s, Me $\left.\mathrm{Me}_{20}\right) ; 2.10$ (s, C $4-\mathrm{OAc}$ ); 2.60 (ddd, $\mathrm{J}=5$ and $\left.14 \mathrm{~Hz}, \mathrm{H}_{2 \alpha}\right) ; 2.68\left(\mathrm{dd}, \mathrm{J}=11\right.$ and $\left.14.3 \mathrm{~Hz}, \mathrm{H}_{6 \alpha}\right) ; 2.78$ (qq, $\mathrm{J}=6.8$ and $\left.6.8 \mathrm{~Hz}, \mathrm{H}_{17}\right) ; 4.60(\mathrm{t}, \mathrm{J}=9 \mathrm{~Hz}) ; 4.75\left(\mathrm{~s}, \mathrm{H}_{15}\right) ; 4.79$ $\left(\mathrm{s}, \mathrm{H}_{4}\right) ; 4.85\left(\mathrm{~s}, \mathrm{H}_{15}\right) ; \mathrm{CMR}\left(\mathrm{CDCl}_{3}, 360 \mathrm{MHz}\right): 150.8(\mathrm{C}-1) ; 27.45$ $(\mathrm{C}-2)^{*} ; 27.25(\mathrm{C}-3)^{*} ; 82.3$ (C-4); 42.6 (C-5); 36.32 (C-6); 65.0 (C-7); $147.5(\mathrm{C}-8)^{+} ; 141.1(\mathrm{C}-9)^{+} ; 26.6(\mathrm{C}-10) ; 42.9$ (C-11); 50.4 (C-12); 45.68 (C-13); 79.3 (C-14); 109.7 (C-15); 17.9 (C-16); 26.9 (C-17); 20.5 (C-18)*; 21.42 (C-19)*; 28.44 (C-20); 169.3 (C 4 -OAc); 22.18 $\left(\mathrm{C}_{4}-\mathrm{OAc}\right)$ (chemical shifts marked with *, ${ }^{*}$ and ${ }^{+}$are interchangeable). High resolution mass measurement: Found: 362.2440 . Calc. for $\mathrm{C}_{22} \mathrm{H}_{34} \mathrm{O}_{4}: 362.2456$.

(4R, 7R, 14S)-4, 7, 14-Trihydroxydolast-1 (15), 8-diene (2). A 
crystalline compound, m.p. $172^{\circ},\{\alpha\}_{\mathrm{D}}=-140^{\circ}\left(\mathrm{c}, 0.05, \mathrm{CHCl}_{3}\right.$ ). MS: $m / z: 320\left(\mathrm{M}^{+}\right), 302,284,259,241$ and 223. IR (KBr): 3500, $3200,2990,1640$ and $910 \mathrm{~cm}^{-1}$. 'H-NMR ( $\left.\mathrm{CDCl}_{3}, 360 \mathrm{MHz}\right): 0.69$ $\left(\mathrm{s}, \mathrm{H}_{16}\right) ; 0.90\left(\mathrm{~d}, \mathrm{~J}=6.8 \mathrm{~Hz}, \mathrm{Me}_{18}\right)^{*}, 1.03\left(\mathrm{~d}, \mathrm{~J}=6.8 \mathrm{~Hz}, \mathrm{Me}_{19}\right)^{*}$; $1.47\left(\mathrm{~s}, \mathrm{Me}_{20}\right) ; 2.83$ (ddd, $\mathrm{J}=5$ and $\left.14 \mathrm{~Hz}, \mathrm{H}_{2 \alpha}\right) ; 2.87 \mathrm{dd}, \mathrm{J}=11$ and $\left.14.2 \mathrm{~Hz}, \mathrm{H}_{6 \alpha}\right) ; 2.90\left(\mathrm{qq}, \mathrm{J}=6.8\right.$ and $\left.6.8 \mathrm{~Hz}, \mathrm{H}_{17}\right) ; 3.45\left(\mathrm{bs}, \mathrm{H}_{4}\right)$; $4.63\left(\mathrm{dd}, \mathrm{J}=11\right.$ and $\left.7 \mathrm{~Hz}, \mathrm{H}_{7}\right) ; 4.78\left(\mathrm{~s}, \mathrm{H}_{15}\right) ; 4.87\left(\mathrm{~s}, \mathrm{H}_{15}\right)$ (chemical shifts marked with ${ }^{*}$ are interchangeable). High resolution mass measurement: Found: 320.2356 . Calc for $\mathrm{C}_{20} \mathrm{H}_{32} \mathrm{O}_{3}: 320.2351$.

(4R, 9S, 14S)-4, 9, 14-Trihydroxydolast-1 (15), 7-diene (7). A crystalline compound, m.p. $220^{\circ},\{\alpha\}_{\mathrm{D}}=-189^{\circ}(c, 0.1, \mathrm{MeOH}) ; \mathrm{IR}$ $(\mathrm{KBr}): 3660,2940,1640,1300,1220,1050,970$ and $910 \mathrm{~cm}^{-1}$. $\left.\mathrm{H}_{2 \alpha}\right) ; 3.35$ (dd, $\mathrm{J}=4$ and $\left.15 \mathrm{~Hz} ; \mathrm{H}_{6 \alpha}\right) ; 3.74\left(\mathrm{~d}, \mathrm{~J}=8 \mathrm{~Hz} ; \mathrm{C}_{14-}\right.$ $\left.\mathrm{Me}_{18}\right)^{*} ; 1.03\left(\mathrm{~d}, \mathrm{~J}=6.8 \mathrm{~Hz}, \mathrm{Me}_{19}\right)^{*} ; 1.23\left(\mathrm{~s}, \mathrm{Me}_{20}\right) ; 1.97(\mathrm{qq}, \mathrm{J}=6.8$ and $\left.6.8 \mathrm{~Hz}, \mathrm{H}_{17}\right) ; 2.65\left(\mathrm{~s}, \mathrm{C}_{4}-0 \mathrm{H}\right) ; 2.89$ (ddd, $\mathrm{J}=5.5$ and $13.6 \mathrm{~Hz}$; $\mathrm{H}_{2 a}$ ); 3.35 (dd, $J=4$ and $\left.15 \mathrm{~Hz} ; \mathrm{H}_{6 a}\right) ; 3.74\left(\mathrm{~d}, J=8 \mathrm{~Hz} ; \mathrm{C}_{14-}\right.$ $\mathrm{OH}) ; 3.47\left(\mathrm{bs}, \mathrm{H}_{4}\right) ; 4.79\left(\mathrm{~s}, \mathrm{H}_{15}\right) ; 4.93\left(\mathrm{~s}, \mathrm{H}_{15}\right) ; 5.63$ (dd, $\mathrm{J}=4$ and $\left.10 \mathrm{~Hz} ; \mathrm{H}_{7}\right)$. CMR $\left(\mathrm{CDCl}_{3}, 360 \mathrm{MHz}\right): 152.3(\mathrm{C}-1) ; 31.2(\mathrm{C}-2)^{*}$; $26.6(\mathrm{C}-3)^{+} ; 79.9$ (C-4); 42.5 (C-5); 29.1 (C-6) $; 119.5$ (C-7); 156.3 (C-8); 86.1 (C-9); 31.3 (C-10)* 41.3 (C-11); 46.0 (C-12); 44.9 (C-13); 81.6 (C-14); 109.7 (C-15); 17.3 (C-16); 37.7 (C-17); 19.1 (C-18)*; 19.9 (C-19)*; 24.4 (C-20) (chemical shifts marked with *, " and ${ }^{+}$are interchangeable). MS: $m / z: 320\left(\mathrm{M}^{+}\right) ; 302,284,277$, 259,241 and 223 . High resolution mass measurement: Found: 320.2351. Calc for $\mathrm{C}_{20} \mathrm{H}_{32} \mathrm{O}_{3}: 320.2336$.

(4R, 9S, 14S)-4-Acetoxy-9, 14-dihydroxydolast-1 (15), 7-diene (8). A viscous and colourless oil, $\{\alpha\}_{\mathrm{D}}=-159^{\circ}\left(c, 0.11, \mathrm{CHCl}_{3}\right)$. IR $\left(\mathrm{CHCl}_{3}\right)$ : $3570,2950,1730,1640$ and $920 \mathrm{~cm}^{-1}$. ${ }^{1} \mathrm{H}$ NMR $\left(\mathrm{CDCl}_{3}, 360 \mathrm{MHz}\right): 0.83\left(\mathrm{~d}, \mathrm{~J}=6.8 \mathrm{~Hz}, \mathrm{Me}_{18}\right): 0.89\left(\mathrm{~s}, \mathrm{Me}_{16}\right)^{*} ; 1.03$ $\left(\mathrm{d}, \mathrm{J}=6.8 \mathrm{~Hz}, \mathrm{Me}_{19}\right) * ; 1.23$ (s, Me 20 ); 2.15 (s, 4-OAc); 2.71 (ddd $\mathrm{J}=5$ and $\left.14 \mathrm{~Hz} ; \mathrm{H}_{2 \alpha}\right) ; 1.95\left(\mathrm{qq}, \mathrm{J}=6.8\right.$ and $\left.6.8 \mathrm{~Hz}, \mathrm{H}_{17}\right) ; 3.06$ (dd, $\mathrm{J}=4$ and $\left.15 \mathrm{~Hz}, \mathrm{H}_{6 \alpha}\right) ; 3.73\left(\mathrm{~d}, \mathrm{~J}=2.4 \mathrm{~Hz}, \mathrm{C}_{14}-\mathrm{OH}\right) ; 4.82(\mathrm{bs}$, $\left.\mathrm{H}_{15}\right) ; 4.85\left(\mathrm{brt}, \mathrm{H}_{4}\right) ; 4.92$ (bs, $\left.\mathrm{H}_{15}\right) ; 5.53$ (dd, $\mathrm{J}=4$ and $9.5 \mathrm{~Hz}, \mathrm{H}_{7}$ ). CMR ( $\left.\mathrm{CDCl}_{3}, 360 \mathrm{MHz}\right): 151.3(\mathrm{C}-1) ; 30.4(\mathrm{C}-2)^{*} ; 26.8(\mathrm{C}-3)^{*} ; 82.0$ (C-4); 42.7 (C-5); 28.3.(C-6)*; 117.9 (C-7); 157.4 (C-8); 86.4 (C-9); 29.3 (C-10)*; 41.4 (C-11); 46.3 (C-12); 43.3 (C-13); 79.7 (C-14); 109.8 (C-15); 17.3 (C-16); 37.8 (C-17); 19.1 (C-18) ${ }^{+} ; 19.9$ (C-19) $^{+}$; 24.4 (C-20); $169.5\left(\mathrm{C}_{4}-\mathrm{OAc}\right) ; 21.4\left(\mathrm{C}_{4}-\mathrm{OAc}\right)$ (chemical shifts marked with *, \# and ${ }^{+}$are interchangeable). MS: $m / z: 362\left(\mathrm{M}^{+}\right), 344$, $319,301,259,241$ and 223. High resolution mass measurement: Found: 362.2445 . Calc for $\mathrm{C}_{22} \mathrm{H}_{34} \mathrm{O}_{4}: 362.2456$.

$(4 \mathrm{R}, 9 \mathrm{R}, 14 \mathrm{~S})-4,9,14-$ Trihydroxydolast -1 (15), 7-diene (9). A crystalline compound, m.p. $160-161^{\circ},\{\alpha\}_{\mathrm{D}}=59^{\circ} \mathrm{c}, 0.1, \mathrm{CHCl}_{3}$ ). IR $\left(\mathrm{CHCl}_{3}\right) ; 3500,2980,1640,1040,960$ and $920 \mathrm{~cm}^{-1} .{ }^{1} \mathrm{H}-\mathrm{NMR}$ $\left(\mathrm{CDCl}_{3}, 360 \mathrm{MHz}\right) ; 0.76\left(\mathrm{~s}, \mathrm{Me}_{16}\right) ; 0.83\left(\mathrm{~d}, \mathrm{~J}=6.8 \mathrm{~Hz}, \mathrm{Me}_{18}\right)^{*} ; 0.99$ $\left(\mathrm{d}, \mathrm{J}=6.8 \mathrm{~Hz}, \mathrm{Me}_{19}\right)^{*} ; 1.40$ (s, $\left.\mathrm{Me}_{20}\right) ; 1.83$ (qq, $\mathrm{J}=6.8$ and $6.8 \mathrm{~Hz}$; $\left.\mathrm{H}_{17}\right) ; 2.84$ (ddd, $\mathrm{J}=4.5$ and $\left.13.6 \mathrm{~Hz} ; \mathrm{H}_{2 \alpha}\right) ; 3.21\left(\mathrm{bs}, \mathrm{H}_{4}\right) ; 3.29$ (dd, $\mathrm{J}=4$ and $\left.15 \mathrm{~Hz}, \mathrm{H}_{6 \alpha}\right) ; 4.71\left(\mathrm{~s}, \mathrm{H}_{15}\right) ; 4.86\left(\mathrm{~s}, \mathrm{H}_{15}\right) ; 5.65(\mathrm{dd}, \mathrm{J}=4$ and $\left.9 \mathrm{~Hz} ; \mathrm{H}_{7}\right)$. CMR $\left(\mathrm{CDCl}_{3}, 360 \mathrm{MHz}\right): 152.4(\mathrm{C}-1) ; 31.2(\mathrm{C}-2)^{+}$; 27.7 (C-3); 80.0 (C-4); 43.1 (C-5); 31.9 (C-6); 120.8 (C-7); 157.6 (C-8); 85.0 (C-9); 32.5 (C-10) ; 42.06 (C-11); 45.5 (C-12); 43.4 (C-13); 81.6 (C-14); 109.5 (C-15); 17.16 (C-16); 34.8 (C-17); 19.0 $(\mathrm{C}-18)^{*} ; 20.17$ (C-19) $^{*} ; 26.6$ (C-20) (chemical shifts marked with ${ }^{*},{ }^{*}$ and ${ }^{+}$are interchangeable). MS: $m / z: 320\left(\mathrm{M}^{+}\right), 284,277,259$, 241 and 223. High resolution mass measurement: Found: 320.2300. Calc. for $\mathrm{C}_{20} \mathrm{H}_{32} \mathrm{O}_{3}: 320.2351$.
Acetylation of 2 and 3 to $4.20 \mathrm{Mg}$ of 2 and $35 \mathrm{mg}$ of 3 were treated separately with excess $\mathrm{Ac}_{2} \mathrm{O}$ in pyridine at room temp overnight and diluted with ether. The mixtures were washed with several portions of $1 \% \mathrm{HCl}$ followed by sat. $\mathrm{NaHCO}_{3}$ aq. The ethereal layer was dried with $\mathrm{MgSO}_{4}$ and the solvent removed under vacuum in both cases. The residues were chromatographed on silica gel (open column) to give 4 in both reactions, and whose 'H-NMR and physical constants were similar to those reported.

Acetylation of 7 to 8 . By employment of the above procedure, $7(30 \mathrm{mg})(0.09 \mathrm{mmole})$ yielded $8(30.5 \mathrm{mg})(0.081 \mathrm{mmole}, 90 \%)$, which was identified by direct comparison with the natural product.

Acetylation of 9 to 6 . Triol $9(20 \mathrm{mg} ; 0.06 \mathrm{mmole})$ was treated with $\mathrm{Ac}_{2} \mathrm{O} / \mathrm{Py}$ under conditions described for the conversion of 7-8. Standard work-up gave 6 as a colourless oil, which was identified by direct comparison with the natural product.

Conversion of 4 to 6 . A soln of $28 \mathrm{mg}(0.068 \mathrm{mmole})$ of 3 in $3 \mathrm{ml}$ DMSO was heated at $120^{\circ}$ for $0.5 \mathrm{hr} . \mathrm{H}_{2} \mathrm{O}$ was added and the mixture was extracted with $\mathrm{CCl}_{4}$. After drying with $\mathrm{MgSO}_{4}$, it was concentrated in vacuo and chromatographed over silica gel to yield $18 \mathrm{mg} \mathrm{(65 \% )}$ of 6 , identical with the natural product.

Conversion of 8 to 6. Compound 8 ( $40 \mathrm{mg}, 0.1$ mmole) was warmed in DMSO under the conditions described for the conversion of 3-6. Removal of solvents in vacuo gave $21 \mathrm{mg}(60 \%)$ of an oil identified as 6 by direct comparison.

Acknowledgements - We thank Prof. Masamitsu Ochi, who generously provided small samples of amijiol. Thanks are also given to Prof. S. García-Blanco for his support and to the Centro de Proceso de Datos de JEN, Madrid, for computer facilities.

This research was supported in part by Grant No. 0153/81 awarded by the CAICT. A. P. Rivera thanks the ICI for a
fellowship.

\section{REFERENCES}

'W. Fenical, Marine Natural Products. Chemical and Biological Perspectives (Edited by P. J. Scheuer) Vol. III. Academic Press, New York (1978) and refs cited.

${ }^{2}$ Bentos I Expedition, organized by the Instituto de Tecnología Pesquera de Taliarte, Las Palmas, Oct. 1981.

This communication was presented in the IVth IUPAC Int. Sym. Marine Natural Products, Teneriffe, 26-30 July 1982.

${ }^{4}$ P. Main, Multan-80, Department of Physics, University of York, York, England 1980.

${ }^{5}$ J. M. Stewart, F. A. Kundell and J. C. Baldwin, The X-ray 70 System. Computer Science Center, University of Maryland, College Park, MD 190.

M. Martínez-Ripoll and J. Fayos, CONFAB, Instituto Rocasolano, CSIC, Serrano 119, Madrid 6, Spain (1977).

${ }^{7}$ H. H. Sun, O. J. McConnell, W. Fencial, K. Hirotsu and J. Clardy, Tetrahedron 37, 1237 (1981).

${ }^{8}$ P. Crews, T. E. Klein, E. R. Hogue and B. L. Myers, J. Org. Chem. 47, 811 (1982).

${ }^{9}$ M. Ochi, M. Watanabe, M. Teniguchi and T. Tokoroyama, Chem. Letters 1229 (1980). 